\title{
An Innovative Methanol Synthesis Process Based on Self-Heat Recuperation
}

Yasuki Kansha, Masanori Ishizuka, Chunfeng Song, Atsushi Tsutsumi*

Collaborative Research Center for Energy Engineering, Institute of Industrial Science,

The University of Tokyo, 4-6-1 Komaba, Meguro-ku, Tokyo 153-8505, Japan

*Corresponding author. Tel.: +81-3-5452-6727, fax: +81-3-5452-6728

E-mail address: $\underline{\text { a-tsu2mi@iis.u-tokyo.ac.jp }}$ 


\section{ABSTRACT}

The demand for methanol will continue to increase since methanol is an attractive fuel for fuel cells in addition to being an intermediate raw material for hydrogen and dimethyl ether (DME), which are categorized as green energy sources. To produce methanol with a minimum amount of energy, it is necessary to investigate and reconsider a whole methanol synthesis process from energy saving point of view. Recently, we developed an innovative process design technology referred to as self-heat recuperation technology for saving energy. To apply this technology, whole-process heat is recirculated within the process without heat addition leading to large energy savings. In this paper, the feasibility of applying self-heat recuperation technology to the methanol synthesis process is investigated and an innovative process for methanol synthesis is developed from an energy saving point of view. The use of this self-heat recuperation technology in the methanol synthesis process greatly reduces the energy consumption.

KEYWORDS: Methanol Synthesis; Energy; Self-Heat Recuperation; Process Design 


\section{Introduction}

The demand for methanol will continue to increase since methanol is attractive as a fuel for fuel cells and is an intermediate raw material in the production of hydrogen [1] and dimethyl ether (DME) [2], which are categorized as green energy sources [3]. In addition to other chemical processes, many methanol synthesis processes have reactant recycle systems with a product separation step because of the low conversion ratio of the reactor. For product separation from the reactant recycle stream, a gas-liquid separator or distillation process is often used in many chemical processes. However, these gas-liquid separator and distillation processes are well known energy-consuming processes because of the latent heat of condensation.

Currently, most methanol is produced from fuel, especially natural gas, coal and biomass by steam reforming and gasification reactions [4]. At first, methane from the fuel is mixed with steam and reformed to carbon monoxide and hydrogen with a catalyst [5]. Then, a methanol and water mixture is produced from carbon monoxide and hydrogen [6]. The methanol synthesis reactions are mainly the following three reactions: $\mathrm{CO}$ and $\mathrm{CO}_{2}$ hydrogenation and the reverse water-gas shift reaction [7]

$$
\begin{array}{lr}
\mathrm{CO}(\mathrm{g})+2 \mathrm{H}_{2}(\mathrm{~g}) \leftrightarrow \mathrm{CH}_{3} \mathrm{OH}(\mathrm{g}) \quad \Delta H_{298}=-90.55 \mathrm{~kJ} \mathrm{~mol}^{-1} \\
\mathrm{CO}_{2}(\mathrm{~g})+3 \mathrm{H}_{2}(\mathrm{~g}) \leftrightarrow \mathrm{CH}_{3} \mathrm{OH}(\mathrm{g})+\mathrm{H}_{2} \mathrm{O}(\mathrm{g}) \Delta H_{298}=-49.43 \mathrm{~kJ} \mathrm{~mol}^{-1}
\end{array}
$$




$$
\mathrm{CO}_{2}(\mathrm{~g})+\mathrm{H}_{2}(\mathrm{~g}) \leftrightarrow \mathrm{CO}(\mathrm{g})+\mathrm{H}_{2} \mathrm{O}(\mathrm{g}) \quad \Delta H_{298}=+41.12 \mathrm{~kJ} \mathrm{~mol}^{-1}
$$

where $\Delta H_{298}$ is the heat of reaction at standard temperature and pressure, i.e. $298 \mathrm{~K}$ and 1 atm. From a thermodynamic equilibrium point of view, Eqs. (1)-(3) indicate that suitable conditions for this methanol synthesis reaction are low temperature and high pressure. Therefore, many chemical engineers and investigators have managed to produce a catalyst that achieves high conversion from reactant to product under low temperature and high pressure conditions in the reactor [8] thus reducing the recycle flow rate because of an increase in the operation's energy [9] or integration of the methanol plant with other plants for whole process optimization [10] of the economics [11] or the operational energy [12].

Recently, we [13] developed self-heat recuperation technology in which the latent heat as well as the sensible heat of the process stream can be circulated without any heat addition, leading to a reduction in the energy requirement of several chemical processes [14]. This self-heat recuperation technology is suitable for thermal and separation processes and can be applied to several chemical processes for energy savings. These include petrochemical distillation [15] such as separation of a benzene-toluene mixture [16], bioethanol distillation, crude oil distillation [17], drying, gas separation [18], and $\mathrm{CO}_{2}$ capture process [19]. 
In this research, we investigated the feasibility of applying self-heat recuperation technology to the methanol synthesis process and we developed an innovative process for methanol synthesis from an energy savings point of view. Using self-heat recuperation technology in the methanol synthesis process greatly reduces the energy consumption of the process. Thus, we expect that the use of self-heat recuperation technology in methanol synthesis is a new process design option that achieves high conversion in the reactor.

\section{Application of self-heat recuperation technology to methanol synthesis}

Self-heat recuperation technology [13] facilitates the recirculation of latent heat and also sensible heat in a process. It helps to reduce the energy consumption of the process using compressors and self-heat exchangers based on exergy recuperation. In this technology, i) a process unit is divided on the basis of functions to balance the heating and cooling loads by performing enthalpy and exergy analyses and ii) the cooling load is recuperated by compressors and exchanged with a heating load [20]. As a result, the heat of the process stream is perfectly circulated without heat addition, and thus exergy loss during heat transfer [21]. The energy consumption of a process can be greatly reduced. 
Methanol is produced from reformed carbon monoxide and hydrogen from a fuel mixture together with a catalyst. After the reactions take place in the reactor, the product mixture from the reactor contains the methanol product as well as water because of the sub-reactions shown by Eqs. (2) and (3), in addition to reactant gases. As for many other chemical processes this methanol synthesis processes consists of a reactant recycle system including product separation. For product separation from the reactant recycle stream, the product mixture from the reactor is fed through a gas-liquid separator to achieve high reaction conversion. The product that contains the methanol and water mixture is fed into the distillation processes to purify the methanol [22]. Fig. 1 shows a flow diagram of the targeted methanol synthesis process [23]. This methanol process was constructed as a pilot plant named the LPMEOH ${ }^{\mathrm{TM}}$ Demonstration Unit.

Based on self-heat recuperation the process streams in this methanol synthesis process were analyzed based on energy and exergy for the application of self-heat recuperation technology. The process was then divided into functions, namely the reaction section and the separation section. The cooling load in each section was recuperated by compressors and exchanged by compression work. 


\section{Simulation Results}

A simulation was conducted using PRO/II Ver. 9.0 (Invensys, SimSci) to examine the energy required for the self-heat recuperative methanol synthesis process and to compare it to that of the methanol synthesis process (LPMEOH ${ }^{\mathrm{TM}}$ Demonstration Unit [23]) with and without heat recovery. In this simulation, the Soave-Redlich-Kwong equation was selected for the thermodynamics data and $100 \%$ adiabatic efficiency was assumed for the compressors. In addition, the minimum temperature difference for the heat exchangers was fixed at $10 \mathrm{~K}$ for all the heat exchangers and the heat and pressure losses from the system are negligible. To ensure the effect of self-heat recuperation and heat recovery the flow diagram can be modified as shown in Fig. 2 and the feed and reactor conditions were fixed at $105 \mathrm{~F}(313.7 \mathrm{~K})$ and $735 \mathrm{psi}(5.07 \mathrm{MPa})$, and $402 \mathrm{~F}$ (478.7 K) and 735 psi $(5.07 \mathrm{MPa})$. Table 1 shows the representative stream conditions of the reaction section in this process as outlined in Fig. 2.

\section{$\underline{\text { Reaction section }}$}

The reaction section consists of a gas mixer to compose a reactant feed stream, a pre-heater to increase the temperature of the reactant streams from the feed temperature to the reaction temperature, a reactor under assumed isothermal conditions, an after-cooler to decrease the temperature of the product stream to $105 \mathrm{~F}$, and a separator to separate the recycle and crude methanol streams from the product mixture. We 
assumed that only the reactions represented in Eqs. (1) and (2) take place in this reactor to simplify the simulation. The amount of reaction heat in the isothermal reactor was 8.8 MW. We assumed that exothermic heat could not be used for heat recovery because it was used for liquid catalyst vaporization in the $\mathrm{LPMEOH}^{\mathrm{TM}}$ Demonstration Unit reactor. The pre-heater duty was 4.5 MW and the after-cooler duty was 7.5 MW, which included methanol and water condensation heat. When applying heat recovery with the feed-effluent heat exchanger the additional heat duty was $0.5 \mathrm{MW}$ because of temperature differences and the after-cooler duty was 3.5 MW when the desired separator temperature was reached. In contrast, when we applied self-heat recuperation technology to the pre-heater and the after-cooler, the net work required to recuperate the heat exergy of the effluent stream was 0.1 ( $=0.4$ for compression and -0.3 from the expander) MW and the after-cooler duty was 3.0 MW to reach the temperature of the separator as shown in Fig. 3.

\section{$\underline{\text { Separation section }}$}

The separation section consisted of a valve to depressurize the crude methanol stream from the reaction section ( $85 \mathrm{psi}(586 \mathrm{kPa})$ ), two heaters to increase the temperature of the streams to the required separation temperatures $(183 \mathrm{~F}(357 \mathrm{~K})$ and $234 \mathrm{~F}(385 \mathrm{~K}))$, two separators to purify the product methanol (96.9 mol\% and $99.8 \mathrm{~mol} \%)$, and three 
coolers to cool the product streams to the feed temperature (105 F), as shown in Fig. 4. In the pilot plant, the second separator is a distillation column because the product mixture includes other hydrocarbons. However, we assumed that only methanol was produced in the reactor as in Eqs. (1) and (2) in this simulation. Thus, we used a flash separator for this separation. The sum of the heater duties (0.6 and $1.2 \mathrm{MW})$ was 1.8 MW, which was equal to the sum of the cooler duties. When applying heat recovery, heat of $0.9(=0.8+0.1) \mathrm{MW}$ was required as additional heat to reach at the separation temperatures. As in the reaction section, compression work $0.1(=0.1+0.0) \mathrm{MW}$ was required to recuperate the process stream using the self-heat recuperation technology in the separation section as shown in Fig. 5.

\section{Discussion}

The energy required for these three processes in the simulation are summarized in Table 2. Although power generation efficiency of $36.9 \%$ (from the Japanese energy saving law) was taken into account, the energy consumption of the reactant recycling system in the reaction section and in the separation system of the separation section is drastically reduced upon applying the self-heat recuperation technology from Table 2. This means that the energy consumption of the whole process is reduced. 
In addition, for the simulation to be close to the real process, we changed the adiabatic efficiencies of the compressor and expander from $100 \%$ to $80 \%$ and observed the effect of the energy consumption of the whole process. The net work required was $0.2(=0.4$ for compression and -0.2 from the expander) $\mathrm{MW}$ in reaction section and the compression work was $0.1(=0.1+0.0) \mathrm{MW}$ in separation section as shown in Table 2 . This means that the energy consumption of the whole process is not significantly affected by the adiabatic efficiencies.

To date, the gas-liquid separator and the distillation processes for reactant recycling and for the purification of the product methanol are well known energy-consuming processes. Many chemical engineers and investigators have managed to produce new catalysts that achieve high conversion and selectivity from the reactant to the product in the reactor and the energy consumption of the recycle system has been reduced by decreasing the recycle flow rate. However, by applying the self-heat recuperation technology, the process energy required to produce methanol is drastically reduced, especially for reactant recycling. This means that the process can achieve a high conversion ratio over the whole process with low energy demand although the conversion ratio in the reactor is the same. In addition, the reaction conditions in these simulations are fixed. However, the product mixture from the reactor is compressed for 
the application of the self-heat recuperation technology. This means that the equilibrium conversion ratio shifts toward the product side according to Le Chatelier's principle.

Thus, the installation of self-heat recuperation technology is an additional process design option. However, it is necessary to apply economic analysis of the proposed process design. Moreover, the current selection of catalysts or newly developed catalysts may allow changes from an energy point of view.

\section{Conclusions}

In this paper, we examined the feasibility of applying self-heat recuperation technology to methanol synthesis for the development of an innovative integrated process design method from an energy saving point of view. The use of self-heat recuperation technology for methanol synthesis led to a drastic reduction in the energy consumption of the process. This phenomenon shows that a new process design methodology using self-heat recuperation has further energy saving potential for other chemical processes. 


\section{Acknowledgement}

This work was supported by the "Advanced Low Carbon Technology Research and Development Program" of the Japan Science and Technology Agency.

\section{References}

[1] R.F. Horng, C.R. Chen, T.S. Wu, C.H. Chan, Cold start response of a small methanol reformer by partial oxidation reforming of hydrogen for fuel cell, Appl. Therm. Eng. 26 (2006) 1115-1124.

[2] F. Manenti, A.R. Leon-Garzon, Z. Ravaghi-Ardebili, C. Pirola, Systematic staging design applied to the fixed-bed reactor series for methanol and one-step methanol/dimethyl ether synthesis, Appl. Therm. Eng. (2014) DOI: 10.1016/j.applthermaleng.2014.04.011.

[3] Project Planning \& Development Div. of Nippon Steel Co., Development of highly efficient methanol synthesis process with new catalysts Nippon Steel Technical Report 92 (2005) 83-84.

[4] F. Puerari, B. Bosio, G. Heyen, Energy Efficiency Optimisation in Different Plant Solutions for Methanol Production from Biomass Gasification, Chem. Eng. Trans. 37 (2014) 301-306. 
[5] M. Soltanieha, K.M. Azarb, M. Saberb, Development of a zero emission integrated system for co-production of electricity and methanol through renewable hydrogen and $\mathrm{CO}_{2}$ capture, Int. J. Greenhouse Gas Control 7 (2012) 145-152.

[6] L.G.J. van der Ham, H. van den Berga, A. Bennekera, G. Simmelinka, J. Timmera, S. van Weerdena, Hydrogenation of carbon dioxide for methanol production, Chem. Eng. Trans. 29 (2012) 181-186.

[7] M. Farsi, A. Jahanmiri, Methanol production in an optimized dual-membrane fixed-bed reactor, Chem. Eng. Process. 50 (2011) 1177-1185.

[8] K.M. Vanden Bussche, G.F. Froment, A Steady-State Kinetic Model for Methanol Synthesis and the Water Gas Shift Reaction on a Commercial Cu/ZnO/Al $\mathrm{O}_{3}$ Catalyst, J. Catalysis 161 (1996) 1-10.

[9] M.N.M. Fuad, M.A. Hussain, A. Zakaria, Optimization strategy for long-term catalyst deactivation in a fixed-bed reactor for methanol synthesis process, Comput. Chem. Eng. 44 (2012)104-126.

[10] H. Taghdisian, F. Farhadi, M. R. Pishvaie, An optimization-oriented green design for methanol plants, J. Chem. Technol. Biotechnol. 87 (2012) 1111-1120.

[11] L.A. Pellegrini, G. Soave, S. Gamba, S. Langè, Economic analysis of a combined energy-methanol production plant, Appl. Energy 88 (2011) 4891-4897. 
[12] F. Manenti, A.R. Leon-Garzon, G. Bozzano, Energy-process integration of the gas-cooled/water-cooled fixed-bed reactor network for methanol synthesis, Chem. Eng. Trans. 35 (2013) 1243-1248.

[13] Y. Kansha, N. Tsuru, K. Sato, C. Fushimi, A. Tsutsumi, Self-heat recuperation technology for energy saving in chemical processes, Ind. Eng. Chem. Res. 48 (2009) $7682-7686$.

[14] K. Matsuda, K. Kawazuishi, Y. Hirochi, R. Sato, Y. Kansha, C. Fushimi, Y. Shikatani, H. Kunikiyo, A. Tsutsumi, Advanced energy saving in the reaction section of hydro-desulfurization process with self-heat recuoperation technology, Appl. Therm. Eng. 30 (2010) 2300-2306.

[15] K. Matsuda, K. Kawazuishi, Y. Kansha, C. Fushimi, M. Nagao, H. Kunikiyo, F. Masuda, A. Tsutsumi, Advanced energy saving in distillation process with self-heat recuperation technology, Energy 36 (2011) 4640-4645.

[16] Y. Kansha Y., N. Tsuru, C. Fushimi, A. Tsutsumi, Integrated process module for distillation processes based on self-heat recuperation technology, J. Chem. Eng. Jpn. 41 (2010) 446-452.

[17] Y. Kansha, A. Kishimoto, A. Tsutsumi, Application of the self-heat recuperation technology to crude oil distillation, Appl. Therm. Eng. 43 (2012) 153-157. 
[18] Y. Kansha, A. Kishimoto, T. Nakagawa, A. Tsutsumi, A novel cryogenic air separation process based on self-heat recuperation, Sep. Purif. Technol. 77 (2011) 389-396.

[19] A. Kishimoto, Y. Kansha, C. Fushimi, A. Tsutsumi, Exergy recuperative CO2 gas separation in pre-combustion capture, Clean Technol. Environ. Policy 14 (2012) $465-474$.

[20] Y. Kansha, N. Tsuru, C. Fushimi, K. Shimogawara, A. Tsutsumi, An innovative modularity of heat circulation for fractional distillation, Chem. Eng. Sci. 65 (2010) $330-334$.

[21] Y. Kansha, Y. Kotani, M. Aziz, A. Kishimoto, A. Tsutsumi, Evaluation of a self-heat recuperative thermal process based on thermodynamic irreversibility and exergy, J. Chem. Eng. Jpn. 46 (2013) 87-91.

[22] W.L. Luyben, Design and Control of a Methanol Reactor/Column Process, Ind. Eng. Chem. Res. 49 (2010) 6150-6163.

[23] E.C. Heydorn, B.W. Diamond, R.D. Lilly, Commercial-scale demonstration of the liquid phase methanol (LPMEOHTM) process, Final Report (Volume 2: Project Performance and Economics) DE-FC22-92PC90543, Department of Energy National Energy Technology Laboratory, Washington DC, USA (2003) 


\section{List of Tables}

Table 1 Heat and mass balance summary of the reaction section

Table 2 Summary of the energy required

\section{List of Figures}

Figure 1 LPMEOH ${ }^{\mathrm{TM}}$ demonstration unit process flow diagram

Figure 2 Simplified flow diagram of the methanol synthesis process

Figure 3 Detailed flow diagram of the reaction section based on self-heat recuperation

Figure 4 Detailed flow diagram of the separation section

Figure 5 Detailed flow diagram of the separation section based on self-heat recuperation 
Table 1 Heat and mass balance summary of reaction section

\begin{tabular}{cccccccc}
\hline Stream No. & 10 & 20 & 30 & $109 \mathrm{a}$ & $109 \mathrm{~b}$ & 120 & 149 \\
\hline Pressure [psi] & 735 & 735 & 735 & 735 & 735 & 735 & 735 \\
Temperature [F] & 105 & 105 & 105 & 402 & 402 & 105 & 105 \\
\hline Flow Rate & & & & & & & \\
\hline $\mathrm{H}_{2}[\mathrm{kmol} / \mathrm{h}]$ & 1.2 & 35.4 & 730.0 & 1998.7 & 1347.4 & 1347.4 & 1231.3 \\
$\mathrm{CO}[\mathrm{kmol} / \mathrm{h}]$ & 58.0 & 5.3 & 298.3 & 825.8 & 509.3 & 509.3 & 464.7 \\
$\mathrm{~N}_{2}[\mathrm{kmol} / \mathrm{h}]$ & 0.6 & 5.7 & 5.4 & 133.5 & 133.5 & 133.5 & 121.7 \\
$\mathrm{CO}{ }_{2}[\mathrm{kmol} / \mathrm{h}]$ & 0 & 1.4 & 43.1 & 297.3 & 288.4 & 288.4 & 253.1 \\
$\mathrm{MEOH}^{2}[\mathrm{kmol} / \mathrm{h}]$ & 0 & 0 & 0 & 19.3 & 338.0 & 338.0 & 19.3 \\
$\mathrm{H}_{2} \mathrm{O}[\mathrm{kmol} / \mathrm{h}]$ & 0 & 0 & 0 & 0.20 & 9.8 & 9.8 & 0.2 \\
\hline
\end{tabular}

Table 2 Summary of the energy required

\begin{tabular}{ccccc}
\hline & $\begin{array}{c}\text { Conventional } \\
\text { (no heat recovery) }\end{array}$ & $\begin{array}{c}\text { Conventional } \\
\text { (heat recovery) }\end{array}$ & $\begin{array}{c}\text { Proposed } \\
\text { (self-heat recuperation) }\end{array}$ \\
\hline $\begin{array}{c}\text { Reaction } \\
\text { Section }\end{array}$ & $4.5 \mathrm{MW}$ & $0.5 \mathrm{MW}$ & $0.1 \mathrm{MW}^{*}$ & $0.2 \mathrm{MW}^{* *}$ \\
$\begin{array}{c}\text { Separation } \\
\text { Section }\end{array}$ & $1.8 \mathrm{MW}$ & $0.9 \mathrm{MW}$ & $0.1 \mathrm{MW}$ & $0.1 \mathrm{MW}$ \\
\hline Total & $6.3 \mathrm{MW}$ & $1.4 \mathrm{MW}$ & $0.2 \mathrm{MW}$ & $0.3 \mathrm{MW}$ \\
\hline
\end{tabular}

*Net Energy Required (Compressor: 433 kW, Expander: 332 kW)

Adiabatic efficiency: $100 \%$

**Net Energy Required (Compressor: 439 kW, Expander: 218 kW)

Adiabatic efficiency: $80 \%$ 


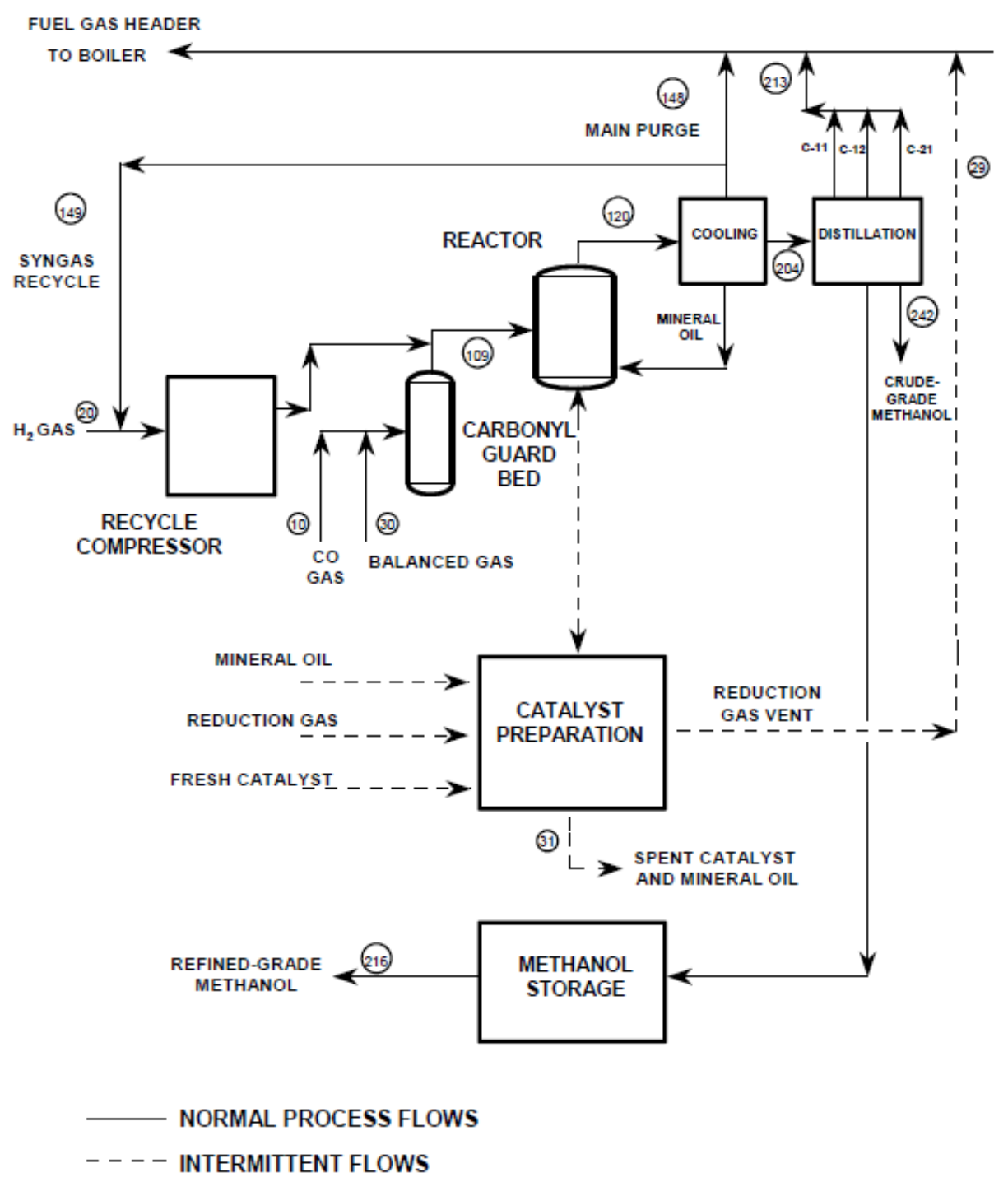

Fig. 1. $\mathrm{LPMEOH}^{\mathrm{TM}}$ demonstration unit process flow diagram [23] 


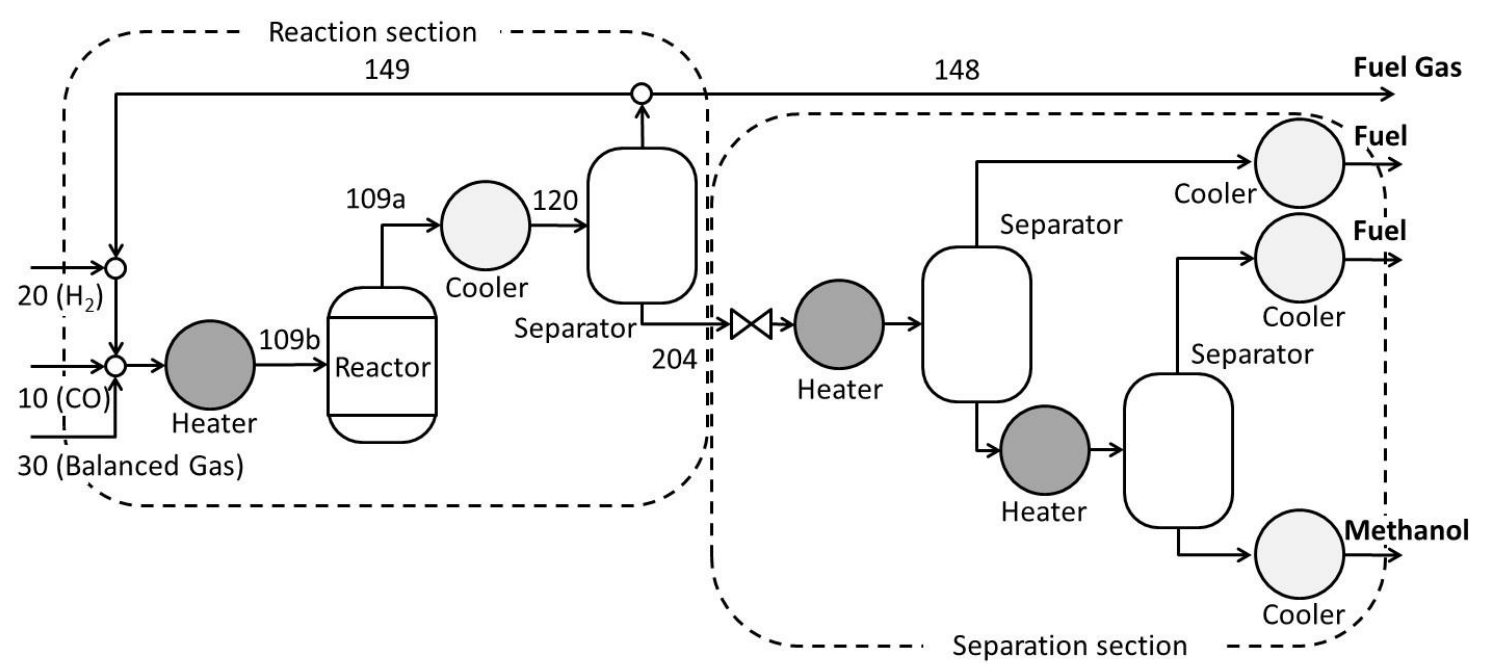

Fig. 2. Simplified flow diagram of the methanol synthesis process

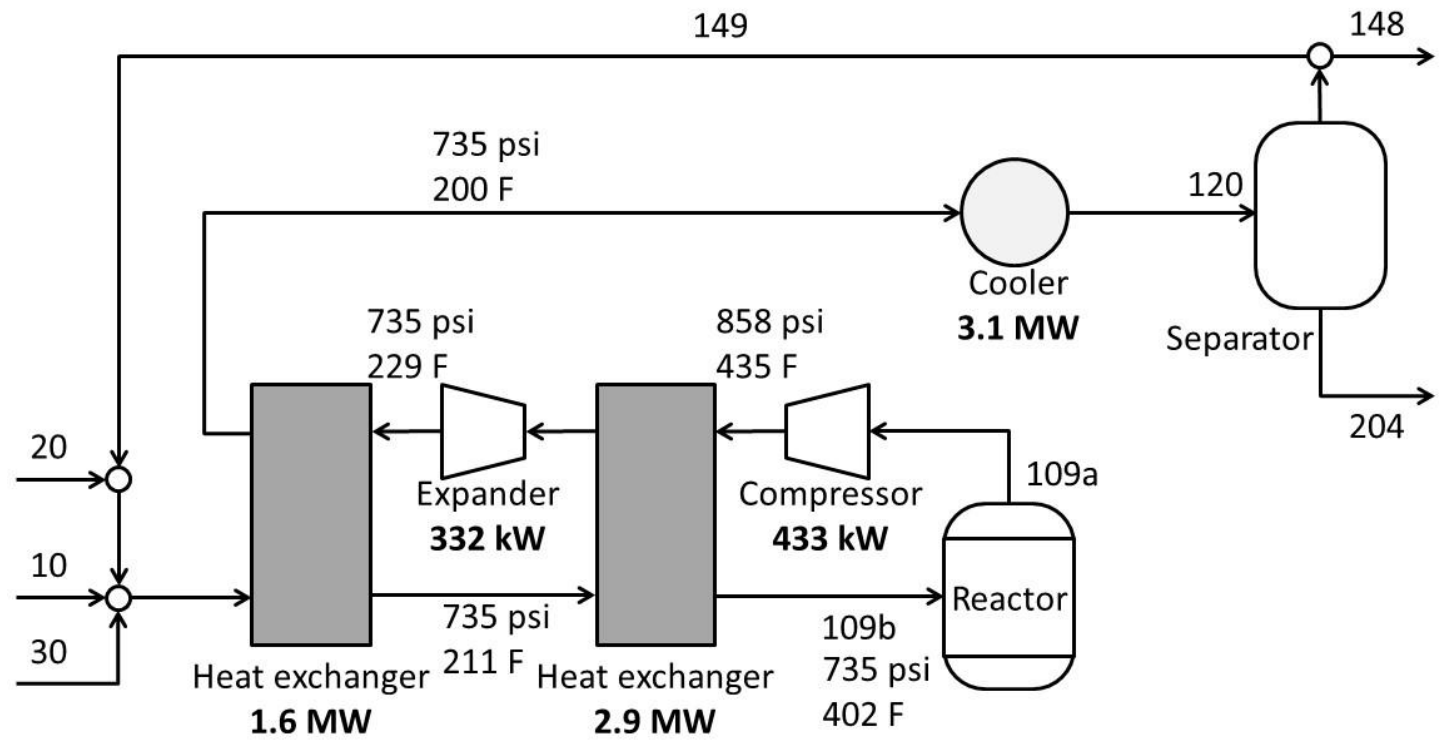

Fig. 3. Detailed flow diagram of the reaction section based on self-heat recuperation 


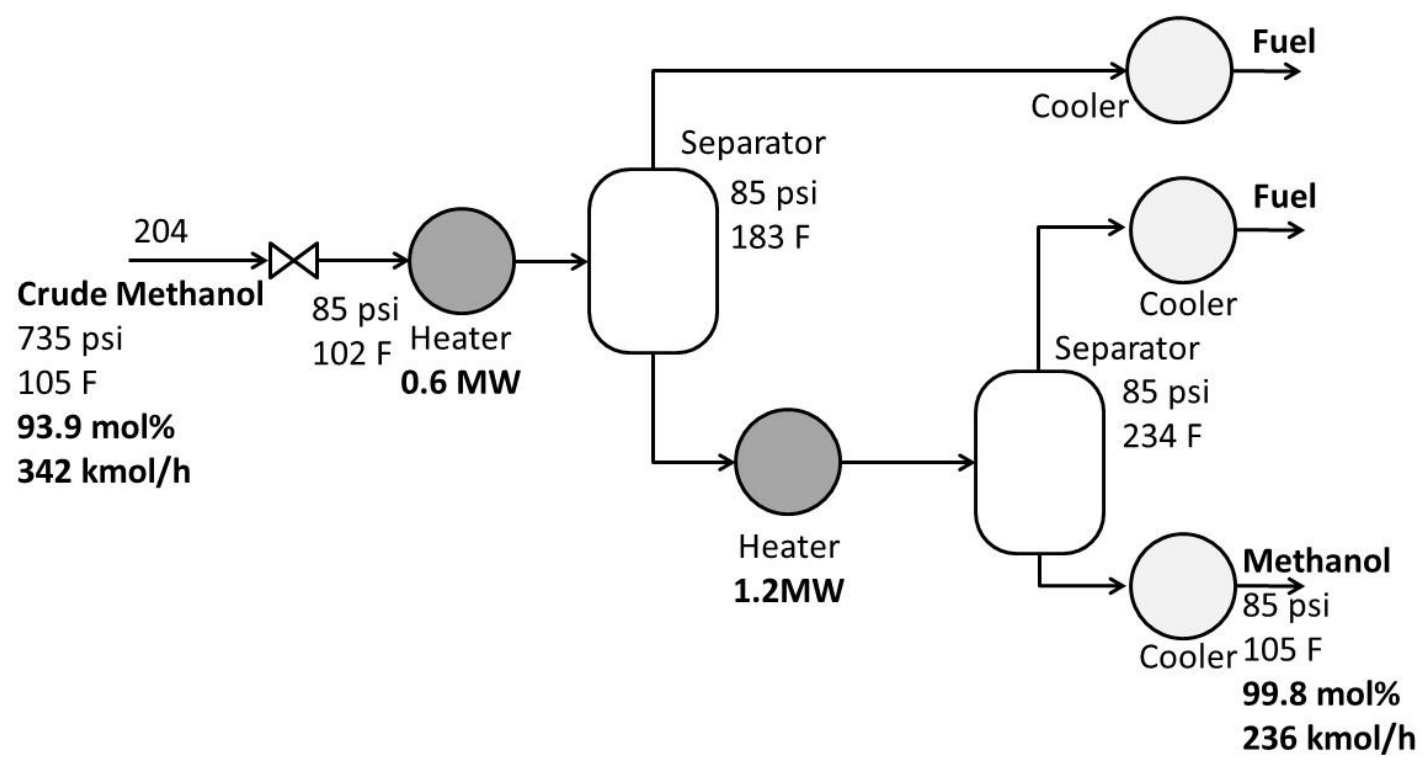

Fig. 4. Detailed flow diagram of the separation section

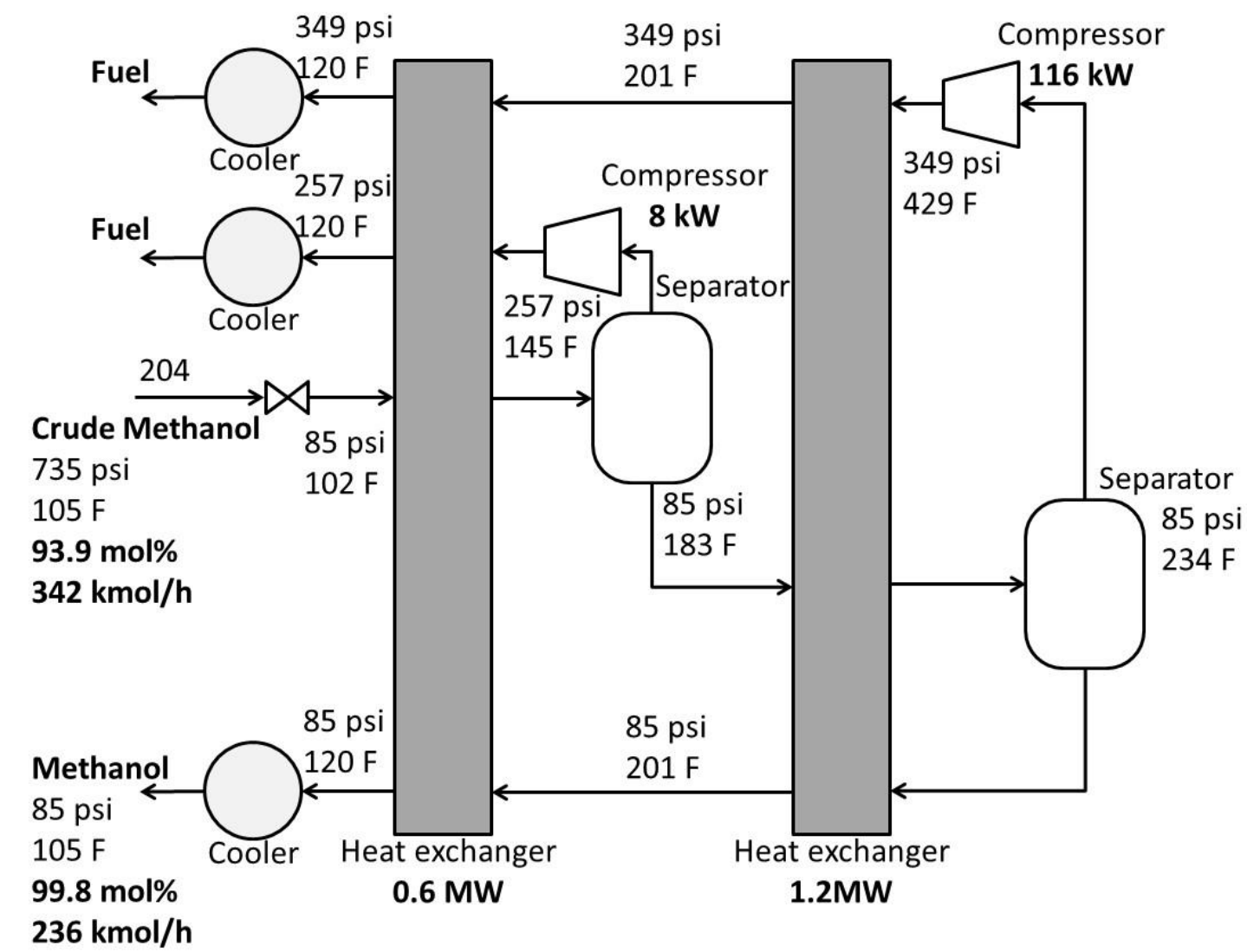

Fig. 5. Detailed flow diagram of the separation section based on self-heat recuperation 